\title{
ANALISIS USAHA KESEHATAN MASYARAKAT BERDASARKAN MANAJEMEN UMUM YANG BERKWALITAS DI PUSKESMAS
}

\author{
Muslim Tasim* \\ * Forum Kepala Puskesmas Kabupaten Lombok Tengah \\ Email:mamathrobby@gmail.com
}

\section{INTISARI}

Usaha Kesehatan Masyarakat merupakan fasilitas pelayanan kesehatan yang menyelenggarakan upaya kesehatan masyarakat tingkat pertama yang mengutamakan upaya promotif dan preventif untuk mencapai derajat kesehatan masyarakat yang setinggi-tingginya. Penenitian ini bertujuan untuk menganalisis usaha Kesehatan masyarakat berdasarkan managemen umum yang berkwalitas di Puskesmas. Pengumpulan data dilakukan dengan observasi langsung, wawancara dan studi literatur berdasarkan kebijakan dan dokumen yang terkait dengan Upaya Kesehatan Masyarakat di Puskesmas. Dokumen yang digunakan sebagai literatur adalah pedoman, kebijakan dan/atau peraturan yang berlaku terkait Upaya Kesehatan Masyarakat di Puskesmas. , Puskesmas memiliki peran sebagai gerbang pertama yang diharapkan bisa memberikan pelayanan kesehatan kepada masyarakat secara komprehensif, tidak hanya melakukan pelayanan kepada perseorangan tetapi juga kepada masyarakat yang lebih luas. Di harapkan Dinas Kesehatan memberikan pelatihan dan bimbingan kepada tim perencana puskesmas dan tenaga struktural Dinas Kesehatan Kabupaten/Kota sehingga mampu juga memberikan bimbingan yang berkesinambungan kepada pemegang program.

Kata Kunci: Usaha Kesehatan Masyarakat, Managemen Puskesmas

\section{PENDAHULUAN}

Pelayanan kesehatan (health care service) merupakan hak setiap orang yang dijamin dalam Undang Undang Dasar 1945 untuk melakukan upaya peningkatkan derajat kesehatan baik perseorangan, maupun kelompok atau masyarakat secara keseluruhan.Defenisi Pelayanan kesehatan menurut Departemen Kesehatan Republik Indonesia Tahun 2009 (Depkes RI) yang tertuang dalam UndangUndang Kesehatan tentang kesehatan ialah setiap upaya yang diselenggarakan sendiri atau secara bersama-sama dalam suatu organisasi untuk memelihara dan meningkatkan kesehatan, mencegah dan menyembuhkan penyakit serta memulihkan kesehatan, perorangan, keluarga, kelompok ataupun masyarakat.

Pusat Kesehatan Masyarakat adalah salah fasilitas pelayanan kesehatan yang menyelenggarakan upaya kesehatan masyarakat dan upaya kesehatan perseorangan tingkat pertama, dengan lebih mengutamakan upaya promotif dan preventif, untuk mencapai derajat kesehatan masyarakat yang setinggi tingginya di wilayah kerjanya (Permenkes No 75 Thn 2014). Jika ditinjau dari sistem pelayanan kesehatan di Indonesia, maka peranan dan kedudukan Puskesmas adalah sebagai ujung tombak sistem pelayanan kesehatan di Indonesia.

Puskesmas " $X$ " Dinas Kesehatan Kabupaten Lombok Tengah merupakan 
salah satu fasilitas pelayanan kesehatan tingkat pertama yang menjalankan fungsinya sebagai penyelenggara Upaya Kesehatan Perorangan (UKP) dan Upaya Kesehatan Masyarakat (UKM) serta bertujuan untuk meningkatkan derajat kesehatan di wilayah kerjanya.

Berdasarkan Permenkes No. 46 Tahun 2015 tentang Akreditasi Puskesmas, Klinik Pratama, Tempat Praktik Mandiri Dokter, dan Tempat Praktik Mandiri Dokter Gigi pada bagian lampiran I Standar Akreditasi Puskesmas menyebutkan bahwa agar Puskesmas dapat menjalankan fungsinya secara optimal perlu dikelola dengan baik mulai dari sumber daya yang digunakan, proses pelayanan hingga kinerja pelayanan sebab masyarakat menghendaki pelayanan kesehatan yang aman dan bermutu, serta dapat menjawab kebutuhan mereka. Oleh karena itu upaya peningkatan mutu, manajemen risiko dan keselamatan pasien perlu diterapkan dalam pengelolaan Puskesmas dalam memberikan pelayanan kesehatan yang komprehensif kepada masyarakat melalui upaya pemberdayaan masyarakat dan swasta (Permenkes, 2015) Oleh karena itu Upaya Kesehatan Masyarakat (UKM) yang merupakan pelayanan promotif dan preventif yang langsung ke tengah-tengah masyarakat perlu mendapat perhatian serius dalam pengelolaan Puskesmas dalam memberikan pelayanan kesehatan yang komprehensif kepada masyarakat melalui upaya pemberdayaan masyarakat dan swasta (Permenkes, 2015).

Upaya Kesehatan Masyarakat meliputi upaya-upaya promosi kesehatan, pemeliharaan kesehatan, pemberantasan penyakit menular, pengendalian penyakit tidak menular, penyehatan lingkungan dan penyediaan sanitasi dasar, perbaikan gizi masyarakat, kesehatan jiwa, pengamanan sediaan farmasi dan alat kesehatan, pengamanan zat adiktif dan bahan berbahaya, serta penanggulangan bencana dan bantuan kemanusiaan.
Upaya Kesehatan Masyarakat yang dilakukan di Puskesmas "X" Dinas Kesehatan Kabupaten Lombok Tengah belum dikatakan optimal, karena dalam tahapan perencanaan kegiatan - kegiatan puskesmas belum terlaksana sesuai dengan manajemen umum perencanaan puskesmas sehingga berdampak pada tidak optimalnya kegiatan - kegiatan yang terlaksana terutama di kemasyarakatan, sehingga banyak kegiatan yang seharusnya dilaksanakan tapi tidak tertuang dalam DPA (Dokumen Pelaksanaan Anggaran) yang ada di puskesmas.

Banyak factor yang menyebabkan masih adanya kegiatan Usaha Kesehatan Masyarakat yang tidak tertuang di DPA Puskesmas, misalnya pengajuaan kegiatan oleh pemegang program yang tidak sesuai dengan analisa situasi, masih melaksanakan kegiatan sebelumnya tanpa kooordinasi dengan pihak lintas sectoral sehingga terkesan copy paste dalam membuat perencanaan kegiatan. Faktor lain adalah kurangnya motivasi masyarakat dalam melaksanakan SMD/MMD dikarenakan pelaksanaan SMD yang seharusnya diselenggarakan oleh masyarakat sendiri dan direalisasikan dari anggaran Puskesmas / desa tidak bisa berjalan seperti yang diharapkan, karena dalam anggarannya masih saja tertuang bahwa yang melaksanakan SMD adalah para petugas dari puskesmas sehingga terkadang kader yang diharapkan untuk melaksanakan SMD tidak termaktub dalam rincian penganggaran. Disinilah mulai terjadi permasalahan manajemen umum perencanaan yang tidak sesuai dengan tahapan siklus manajemen puskesmas yang berkwalitas yang dapat tidak terlaksananya suatu kegiatan yang diperlukan masyarakat. 


\section{METODE}

Artikel ilmiah ini merupakan jenis artikel ilmiah deskriptif. Teknik pengumpulan data yang dilakukan adalah dengan observasi langsung, wawancara dan studi literatur berdasarkan kebijakan dan dokumen yang terkait dengan Upaya Kesehatan Masyarakat di Puskesmas. Observasi langsung dilakukan untuk melihat proses pelaksanaan Upaya Kesehatan Masyarakat di Puskesmas "X" Dinas Kesehatan Kabupaten Lombok Tengah. Wawancara dilakukan kepada Kepala Tata Usaha, Penanggung jawab Usaha Kesehatan Masyarakat dan Ketua Tim Perencanaan dengan menggunakan panduan wawancara yang disesuaikan dengan Permenkes No. 44 Tahun 2016 dan Instrumen Akreditasi Puskesmas. Sedangkan dokumen yang digunakan sebagai literatur adalah pedoman, kebijakan dan/atau peraturan yang berlaku terkait Upaya Kesehatan Masyarakat di Puskesmas. Pengumpulan data dilaksanakan di Puskesmas " $X$ " Dinas Kesehatan Kabupaten Lombok Tengah pada bulan Maret 2020.

\section{HASIL DAN PEMBAHASAN}

Sesuai dengan Permenkes No 75 Tahun 2014, puskesmas memiliki peran sebagai gerbang pertama yang diharapkan bisa memberikan pelayanan kesehatan kepada masyarakat secara komprehensif, tidak hanya melakukan pelayanan kepada perseorangan tetapi juga kepada masyarakat yang lebih luas. Upaya Kesehatan Masyarakat (UKM) menjadi tugas utama puskesmas yang berfokus kepada upaya pencegahan dan promosi kesehatan masyarakat. UKM juga mendorong partisipasi masyarakat untuk terlibat dalam peningkatan kesehatan masyarakat. Untuk memenuhi kebutuhan masyarakat, Puskesmas "X" Dinas Kesehatan Kabupaten Lombok Tengah memiliki UKM Esensial dan UKM Pengembangan.

\section{UKM Esensial}

UKM esensial merupakan upaya kesehatan masyarakat yang telah ditentukan program dan cakupannya di seluruh puskesmas di Indonesia. Upaya-upaya ini ditujukan untuk meningkatkan kesehatan masyarakat pada 5 aspek mendasar dari kesehatan yang saling berkaitan satu dengan yang lain, yaitu kesehatan ibu, anak dan KB; gizi; pencegahan dan pengendalian penyakit; kesehatan lingkungan; dan promosi kesehatan. Bagian dari upaya bersama antara UKP dan UKM bagi masyarakat yang membutuhkan perawatan di rumah, Puskesmas " $X$ " Dinas Kesehatan Kabupaten Lombok Tengah menyediakan fasilitas perawatan kesehatan masyarakat.

\section{a. Upaya Kesehatan Ibu dan Anak serta Keluarga Berencana}

Bentuk-bentuk kegiatan dari upaya kesehatan ini adalah penyuluhan $\mathrm{KB}$, kunjungan rumah pada ibu pasca salin dengan risiko, pelaksanaan SDIDTK pada anak pra sekolah.

b. Upaya Perbaikan Gizi

\section{Masyarakat}

Beberapa contoh kegiatan dalam upaya kesehatan ini adalah penanganan dan pendampingan pada balita gizi buruk, penyuluhan ASI eksklusif, dan pemantauan tumbuh kembang anak melalui Posyandu Balita di setiap pedukuhan.

c. Upaya Pencegahan dan Pengendalian Penyakit

Upaya pencegahan dan pengendalian penyakit dilakukan dengan kegiatan pemantauan dan pendampingan pasien $\mathrm{TB}$, penyelidikan epidemiologi jika ditemukan kasus demam berdarah, campak, diare atau penyakit lain 
yang memungkinkan terjadinya penularan.

\section{d. Upaya Penyehatan Lingkungan}

Kesehatan lingkngan dicapai melalui berbagai kegiatan, beberapa diantaranya adalah pemantauan penggunaan air bersih, deklarasi stop BAB sembarangan, pemantauan jentik secara berkala, pengelolaan sampah yang terstandar, dan pemantauan tata kelola limbah di lingkungan rumah maupun instansi.

\section{e. Upaya Promosi Kesehatan}

Promosi perilaku hidup bersih dan sehat merupakan kunci dari upaya peningkatan kesehatan masyarakat. Perilaku Hidup Bersih dan Sehat (PHBS) terdiri dari 10 indikator, yaitu : persalinan ditolong oleh tenaga kesehatan, memberi bayi ASI eksklusif, menimbang balita setiap bulan di Posyandu, menggunakan air bersih, mencuci tangan dengan sabun, penggunaan jamban sehat, pemberantasan jentik nyamuk, mengkonsumsi sayur dan buah setiap hari, melakukan aktivitas fisik setiap hari, dan tidak merokok. Kegiatan lain dari upaya promosi kesehatan adalah pembinaan dan pendampingan posyandu. Di Puskesmas " $\mathrm{X}$ " Dinas Kesehatan Kabupaten Lombok Tengah sudah mengembangkan system Posyandu Keluarga.

\section{f. Upaya Perawatan Kesehatan Masyarakat}

Untuk pasien atau masyarakat yang membutuhkan perawatan di rumah, Puskesmas "X" Dinas Kesehatan Kabupaten Lombok Tengah menyediakan pelayanan kunjungan rumah oleh tenaga kesehatan yang sesuai dengan permasalahan pasien. Upaya kesehatan ini juga bertujuan untuk menjangkau pasien yang kesulitan mengakses layanan dalam gedung.

\section{UKM Pengembangan}

Berkomitmen untuk terus meningkatkan mutu pelayanan dan bertujuan untuk memenuhi kebutuhan masyarakat, Puskesmas " $\mathrm{X}$ " Dinas Kesehatan Kabupaten Lombok Tengah mengembangkan upaya-upaya kesehatan masyarakat yang terdiri dari upaya kesehatan lansia, remaja, jiwa, dan indera serta UKS.

\section{a. Upaya Kesehatan Lansia}

Pelayanan kesehatan lanjut usia (lansia) bertujuan menyediakan pelayanan kesehatan lanjut usia yang bermutu dan berkesinambungan di puskesmas. Ketersediaan pelayanan ini diharapkan dapat meningkatkan kesadaran para lanjut usia untuk membina kesehatannya secara mandiri, meningkatkan kemampuan dan peran serta keluarga dan masyarakat dalam menghayati dan mengatasi kesehatan, serta meningkatkan jenis dan jangkauan pelayanan kesehatan lanjut usia.

\section{b. Upaya Kesehatan Remaja}

Tahap remaja merupakan tahapan perkembangan yang unik dimana terjadi masa peralihan dari seorang anak menjadi seorang dewasa. Tahapan yang penuh dengan tantangan ini seringkali diikuti dengan munculnya berbagai permasalahan, seperti pergaulan bebas yang mengarah pada kehamilan di usia remaja, penggunaan NAPZA, ataupun kenakalan remaja lainnya. Untuk mendampingi remaja dan meningkatkan kesadaran masyarakat akan pentingnya pendampingan terhadap remaja, Puskesmas "X" Dinas Kesehatan Kabupaten Lombok Tengah menyediakan pelayanan kesehatan remaja. Bentuk pelayanan kesehatan remaja ini diwujudkan 
dalam program Pelayanan Kesehatan Peduli Remaja (PKPR).

\section{c. Upaya Kesehatan Jiwa}

Permasalahan kesehatan jiwa menjadi keprihatinan bersama karena menimbulkan beban psikologis, ekonomi, dan sosial pada individu maupun keluarga. Namun permasalahan ini relatif belum mendapat penanganan yang maksimal oleh tenaga kesehatan. Oleh karena itu, Pelayanan kesehatan jiwa dirasa perlu diinisiasi untuk membantu memelihara dan meningkatkan derajat kesehatan jiwa individu, keluarga dan masyarakat serta lingkungannya. Upaya yang dilakukan antara lain upaya promotif, preventif, kuratif, dan rehabilitatif kepada pasien gangguan jiwa, keluarga dan masyarakat.

\section{d. Upaya Kesehatan Indera}

Kesehatan indera merupakan aspek penting untuk menunjang individu menjalankan peran dan tanggung jawabnya secara optimal. Puskesmas "X" Dinas Kesehatan Kabupaten Lombok Tengah menyediakan fasilitas pelayanan kesehatan indera untuk membantu masyarakat menyadari pentingnya menjaga kesehatan indera dan mengetahui upaya pengobatan yang tepat untuk mengatasi permasalahan kesehatan indera. Pelayanan kesehatan indera merupakan upaya pengembangan dari UKM esensial yang menjadi salah satu kekhasan Puskesmas " $X$ " Dinas Kesehatan Kabupaten Lombok Tengah.

\section{e. Upaya Kesehatan Sekolah}

Upaya Kesehatan Sekolah bertujuan untuk meningkatkan kesehatan siswa dan lingkungan sekolah. UKS menjalankan fungsinya berpedoman pada Trias UKS, yaitu :

1) Pelayanan kesehatan, bentuk kegiatannya adalah pemeriksaan siswa sakit dan screening kesehatan untuk siswa kelas 1

2) Pendidikan kesehatan, bentuk kegiatannya adalah penyuluhan kesehatan kepada siswa

3) Penyehatan lingkungan, bentuk kegiatannya adalah pengelolaan sampah dan upaya kesehatang lingkungan.

Puskesmas "X" Dinas Kesehatan Kabupaten Lombok Tengah menjalankan Trias UKS dan pembinaan UKS bersamasama dengan lintas sector namun belum maksimal.

Sangat menetukannya kegiatan UKM di Puskesmas, apabila tidak dilakukan perencanaan yang baik dalam pelaksanaannya, akan mengakibatkan pelaksanaan kegiatannya tidak sesuai dengan yang diharapkan. Menurut informasi Kepala Tata Usaha dan Penanggung jawab UKM Puskesmas " $\mathrm{X}$ " Dinas Kesehatan Kabupaten Lombok Tengah, banyak kegiatan UKM yang seharusnya sangat dibutuhkan oleh masyarakat tapi tidak bisa dilaksanakan terkendala waktu dan biaya. Pada tahun 2020 ini, terdapat beberapa kegiatan UKM yang seharusnya sangat dibutuhkan masyarakat tapi tidak bisa dilaksanakan, antara lain :

1) Monitoring dan evaluasi Manajemen ke Jaringan dan Jejaring Puskesmas

2) Penyuluhan Kesehatan pada lansia

3) Upaya pencegahan dini terhadap stunting yaitu kegiatan berupa Pendampingan kader pada ibu hamil, Pemeberian Makanan Tambahan pada ibu hamil dan Batita

4) Pembinaan Usaha Kesehatan Sekolah Berdasarkan Permenkes No. 46 Tahun 2015 Lampiran I Standar Akreditasi Puskesmas disebutkan bahwa 
visi pembangunan kesehatan yang diselenggarakan oleh Puskesmas adalah tercapainya Kecamatan Sehat menuju terwujudnya Indonesia Sehat. Untuk mewujudkan tercapainya Kecamatan Sehat, pelayanan kesehatan khususnya Puskesmas harus memiliki kemampuan memberikan pelayanan kesehatan yang bermutu, aman, serta dapat menjawab kebutuhan masyarakat.

Desentralisasi

perencanaan kesehatan sebagai salah satu faktor esensial dalam proses merupakan yang kompleks dan membutuhkan kerjasama yang baik antara penentu kebijkan, perencana, tenaga administrasi dan masyarakat. Oleh karena itu, dibutuhkan tekad yang kuat dan kesiapan yang matang untuk menata dan memperkuat sistem perencanaan kesehatan dpad amasing-masing kabupaten/ kota. (Munif, 2012). Perencanaan program adalah penjabaran dari renstra yang akan dilaksanakan oleh organisasi berdasarkan program. Perencanaan program sering dibedakan atas perencanaan sekali pakai (single use) dan berkesinambungan atau diulang pada tahun-tahun berikutnya (standing use). Dalam penyusunanan program standing use harus disusun dengan melibatkan banyak aspek, sehingga nantinya bisa digunakan sebagai acuan atau panduan atau standar program tahun berikutnya.

Berdasarkan hasil survey langsung ke Puskesmas " $X$ " Dinas Kesehatan Kabupaten Lombok Tengah, diakui oleh Kepala Tata Usaha bahwa proses perencanaan belum dilaksnakan secara maksimal, hal ini dibuktikan bahwa besaran anggaran yang tertuang pada Dokumen Pelaksanaan Pergeseran Anggaran (DPPA) SKPD pada tahun 2020 lebih rendah dari Dokumen Pelaksanaan Pergeseran Anggaran (DPPA) SKPD pada tahun 2019, seperti terlihat pada gambar berikut :

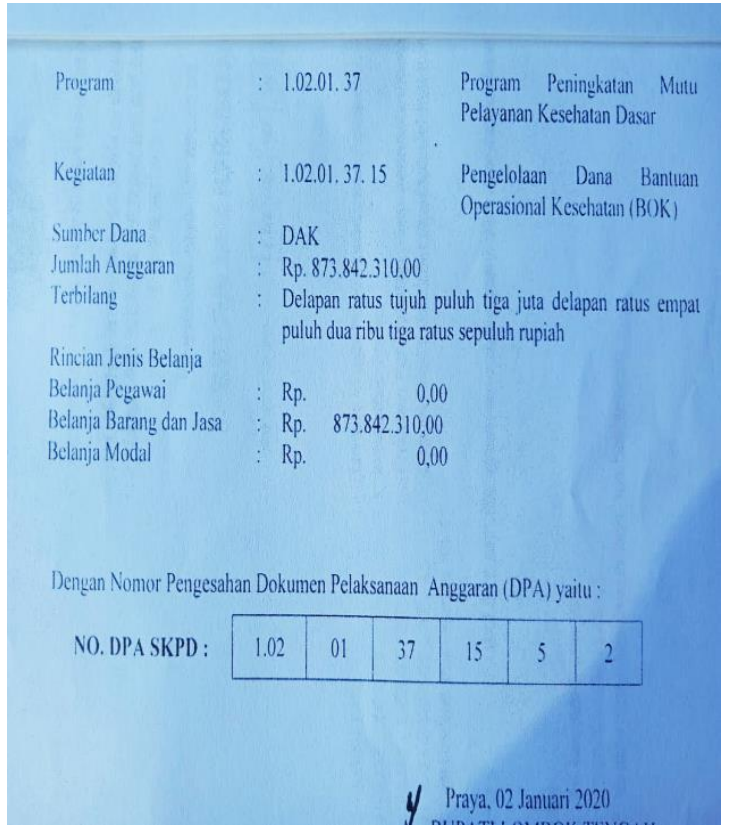

DPPA SKPD Tahun 2020

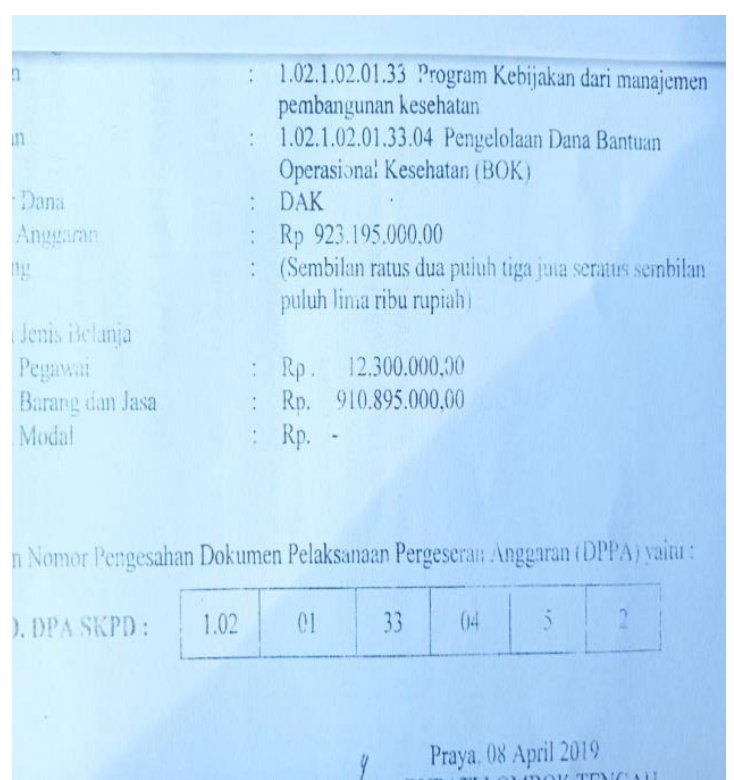

DPPA SKPD Tahun 2019

Disisi lain, jenis kegiatan pada perencanaan yang dibuat terkesan tidak ada jauh berbeda dari tahun sebelumnya, seperti terlihat pada gambar berikut : 
Gambar Kegiatan Tahun 2020 :

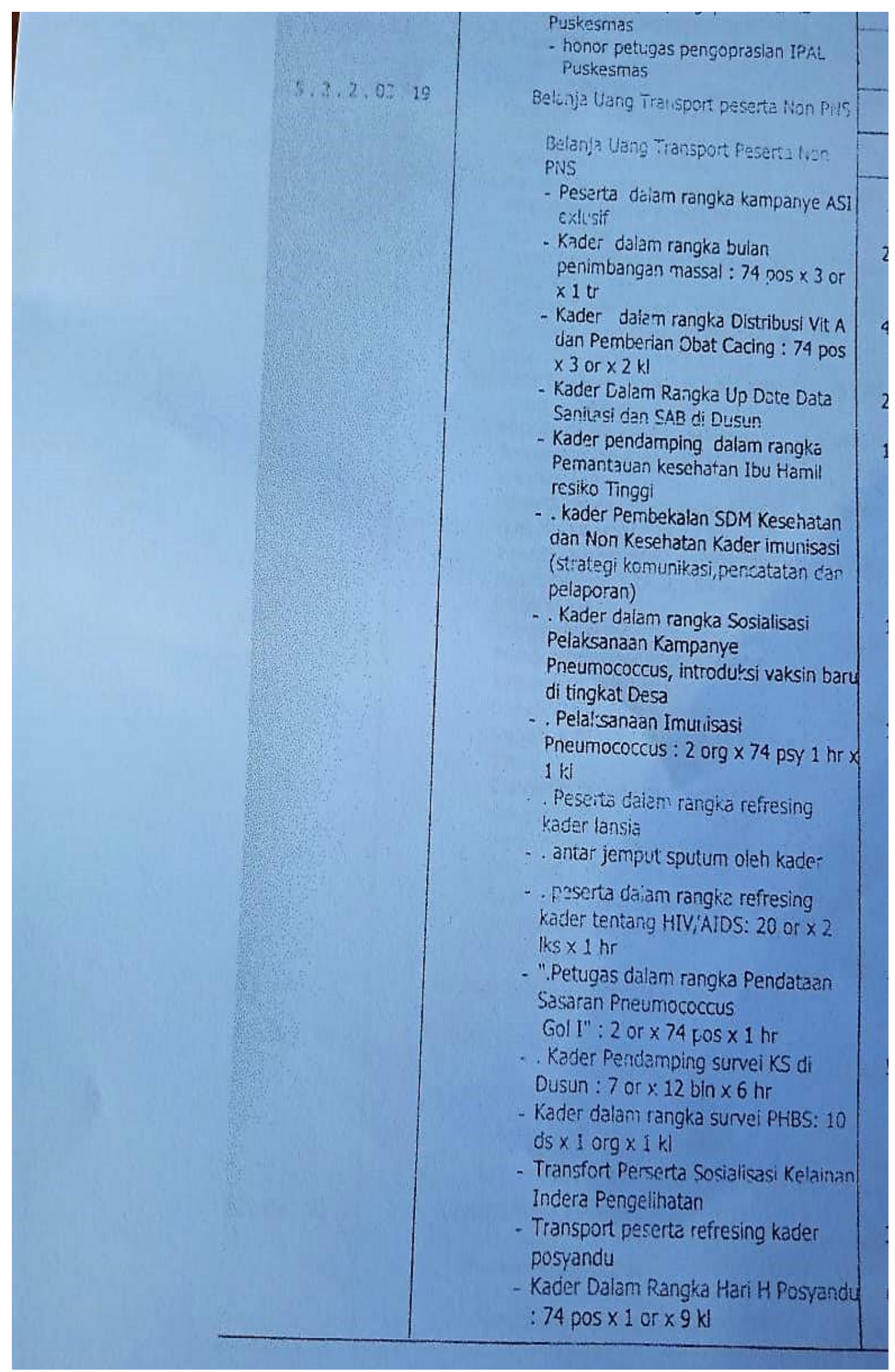


Gambar Kegiatan Tahun 2019 :

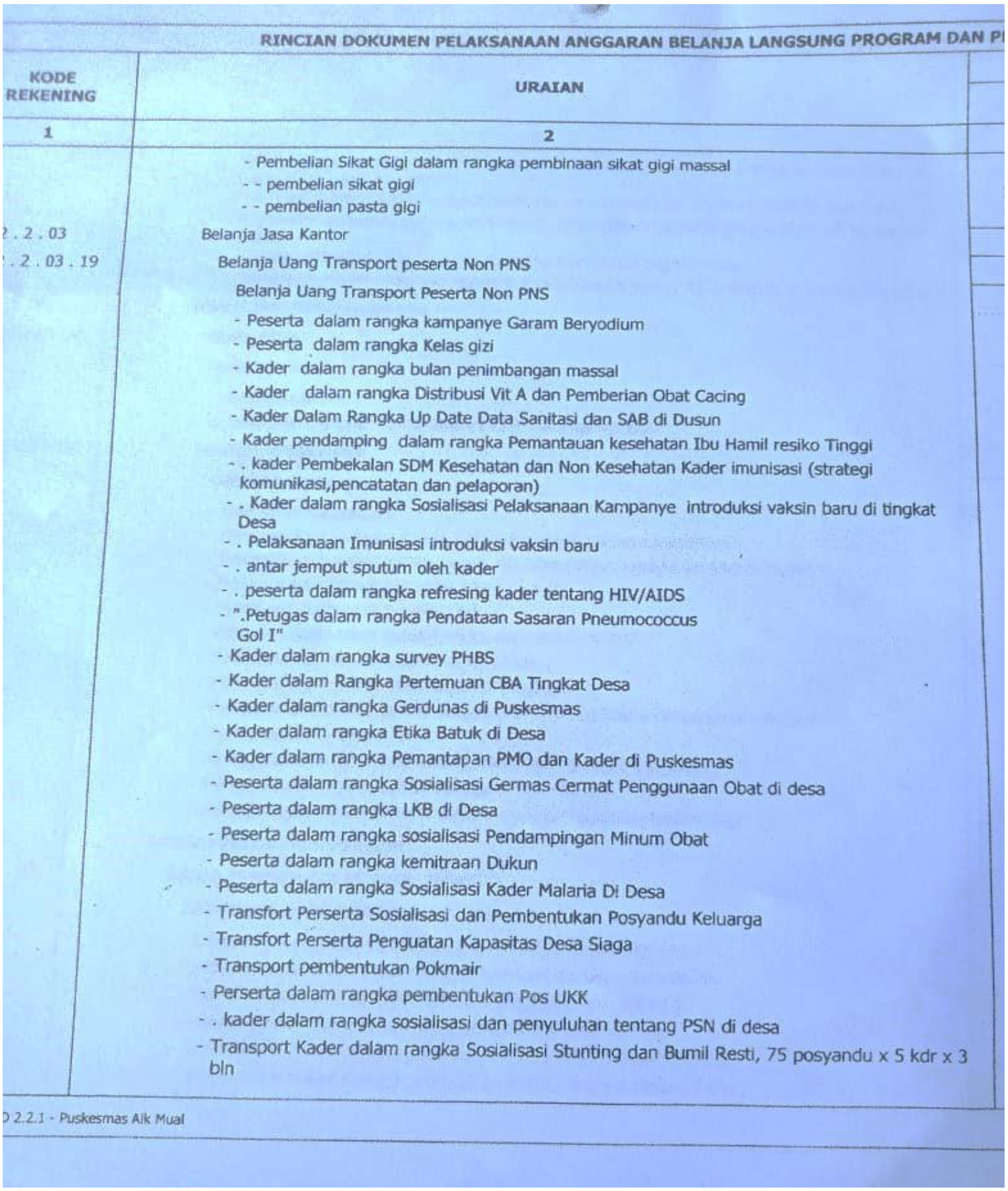

Mendiskripsikan kedua gambar di atas, tampak jelas bahwa kegiatan tahun berjalan sekarang ini diambil dari kegiatan sebelumnya, dimana proses perencanaan yang mengakomodir data internal dan eksternal puskesmas belum berjalan maksimal.

Untuk menunjang pelaksanaan fungsi dan penyelenggaraan upaya puskesmas, puskesmas harus dilengkapi dengan instrumen manajemen yang terdiri dari : 1. PTP (Perencanaan Tingkat Puskesmas) Perencanaan tingkat Puskesmas akan memberikan pandangan menyeluruh terhadap semua tugas, fungsi dan peranan yang akan dijalankan dan menjadi tuntunan dalam proses pencapaian tujuan Puskesmas secara efisien dan efektif. Perencanaan Puskesmas merupakan inti kegiatan manajemen Puskesmas, karena semua kegiatan manajemen diatur dan diarahkan 
oleh perencanaan. Dengan perencanaan Puskesmas, memungkinkan para pengambil keputusan dan pimpinan Puskesmas untuk menggunakan sumber daya Puskesmas secara berdaya guna dan berhasil guna. Untuk menjadikan organisasi dan manajemen Puskesmas efektif dan berkinerja tinggi diawali dari perencanaan efektif. 2. Koordinasi merupakan suatu pertemuan antar petugas Puskesmas dan petugas Puskesmas dengan sektor terkait (lintas sektoral) untuk meningkatkan kerjasama tim, memantau cakupan pelayanan Puskesmas serta membina peran serta masyarakat secara terpadu agar dapat meningkatkan fungsi Puskesmas.

Nock Alberto Yoku tahun 2014 mengemukakan bahwa, menentukan tujuan program harus sesuai dengan keadaan di lapangan, rencana kerja yang baik dan ingin mendapatkan hasil yang baik memerlukan tujuan yang ingin dicapai, dimana tujuan dibagi menjadi dua, yaitu tujuan umum dan tujuan khusus. Penentuan tujuan pada Puskesmas "X" Dinas Kesehatan Kabupaten Lombok Tengah mengengikuti tujuan Dinas Kesehatan Kabupaten Lombok Tengah. Penentuan ini sebagian besar melibatkan kepala puskesmas. Dari tujuan yang telah ditentukan, pada kenyataannya diperoleh masih ada yang kurang realistis dengan kondisi yang ada di lapangan. Hal ini mungkin disebabkan tujuan yang dibuat belum secara detail menjelaskan masalah yang terjadi di wilayah Kabupaten Lombok Tengah

Sehingga, agar Puskesmas dapat menjalankan fungsinya secara optimal perlu dikelola dengan baik, baik kinerja pelayanan, proses pelayanan, maupun sumber daya yang digunakan. Masyarakat menghendaki pelayanan kesehatan yang aman dan bermutu, serta dapat menjawab kebutuhan mereka, oleh karena itu upaya peningkatan mutu, manajemen risiko dan keselamatan pasien perlu diterapkan dalam pengelolaan Puskesmas dalam memberikan pelayanan kesehatan yang komprehensif kepada masyarakat melalui upaya pemberdayaan masyarakat dan swasta. Penilaian keberhasilan Puskesmas dapat dilakukan oleh internal organisasi Puskesmas itu sendiri, yaitu dengan "Penilaian Kinerja Puskesmas," yang mencakup manajemen sumber daya termasuk alat, obat, keuangan dan tenaga, serta didukung dengan manajemen sistem pencatatan dan pelaporan, disebut Sistem Informasi Manajemen Puskesmas (SIMPUS). Untuk menjamin bahwa perbaikan mutu, peningkatan kinerja dan penerapan manajemen risiko dilaksanakan secara berkesinambungan di Puskesmas, maka perlu dilakukan penilaian oleh pihak eksternal dengan menggunakan standar yang ditetapkan yaitu melalui mekanisme akreditasi. Tujuan utama akreditasi Puskesmas adalah untuk pembinaan peningkatan mutu, kinerja melalui perbaikan yang berkesinambungan terhadap sistem manajemen, sistem manajemen mutu dan sistem penyelenggaraan pelayanan dan program, serta penerapan manajemen risiko, dan bukan sekedar penilaian untuk mendapatkan sertifikat akreditasi.

\section{SIMPULAN}

Tujuan dari pelayanan kesehatan adalah untuk memenuhi kebutuhan individu atau masyarakat untuk mengatasi, menetralisasi atau menormalisasi semua masalah atau semua penyimpangan tentang kesehatan yang ada dalam masyarakat. Dengan meningkatnya tingkat pendidikan dan keadaan sosial ekonomi masyarakat, maka kebutuhan dan tuntutan masyarakat akan kesehatan semakin meningkat sehingga tidak ada lagi upaya yang dapat dilakukan selain meningkatkan kinerja petugas kesehatan dan menyelenggarakan pelayanan kesehatan dengan sebaik-baiknya.salah satu upaya yang dilaksanakan di Indonesia dalam rangka peningkatan pelayanan 
kesehatan adalah melalui program Jaminan Kesehatan Nasional ( UU No. 40, 2004).

Pelayanan kesehatan yang berkualitas sangat bergantung pada faktor fundamental manajemen. Pencapaian pelayanan kesehatan yang berkualitas adalah perencanaan yang baik dan tertata rapi, pelaksanaan yang sesuai dengan perencanaan, penunjang kegiatan yang memadai,pencatatan dan pelaporan yang tepat. Pencapaian tersebut sangat terkait dengan faktor manajemen yang baik khususnya pada puskesmas akan sangat berpengaruh pada pelaksanaan pelayanan.

Manajemen upaya kesehatan masyarakat di Puskesmas "X" Dinas Kesehatan Kabupaten Lombok Tengah hendaknya diselenggarakan dengan memperhatikan Standar Pelayanan Minimal ( SPM ). Kegiatan perencanaan utamanya melibatkan seluruh tenaga kesehatan dalam lokakarya mini yang didalamnya termasuk penggalangan kerjasama baik lintas program maupun lintas sektor. Gambaran proses prencanaan sesuai dengan Permenkes no.44 Tahun 2016 dapat dilihat bagan berikut :

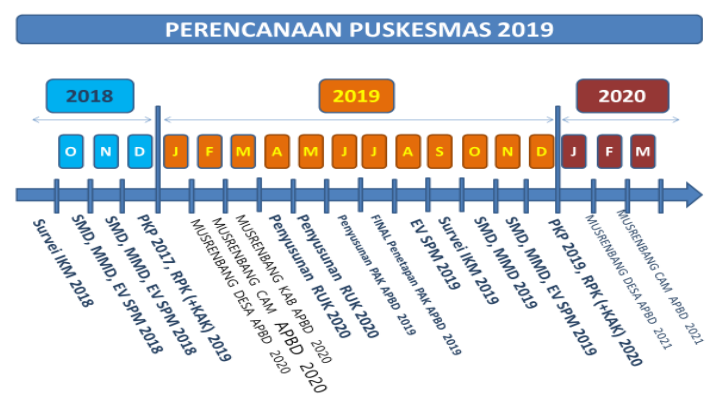

Berdasarkan kesimpulan di atas kami menyarankan agar Dinas Kesehatan Kabupaten Lombok Tengah memberikan pelatihan dan bimbingan kepada tim perencana puskesmas dan tenaga structural Dinas Kesehatan Kabupaten/Kota sehingga mampu juga memberikan bimbingan yang berkesinambungan kepada pemegang program dan memberikan Form yang baku untuk kelengkapan administrasi perencanaan, sehingga mampu untuk melaksanakan pembinaan (supervisi suportif, DQS dan EVSM) ke level di bawahnya serta melakukan pelatihan perencanaan program bagi pemegang program. 


\section{DAFTAR PUSTAKA}

Paramita Boni Lestari, Setya Haksama 2016). Analisis Fungsi Manajemen Logistik Di Badan Pemberdayaan Masyarakat Dan Keluarga Berencana Kota Surabaya. e-journal Fakultas Kesehatan Masyarakat, Universitas Airlangga, Surabaya. 2016

Karlina Okta Viani (2017). Pentingnya Perencanaan dalam Program Imunisasi di Dinas Kesehatan Kota Surabaya. Jurnal Kesehatan Ikatan Bidan Indonesia (IBI) Brebes. JuliDesember 2017.

Nurul Hidayatul Ulumiyah (2018). Meningkatkan Mutu Pelayanan Kesehatan Dengan Penerapan Upaya Keselamatan Pasien Di Puskesmas. Jurnal Kesehatan PERSAKMI Jawa Timur, Indonesia. Desember 2018.

Kementerian Kesehatan Republik Indonesia. 2016. Peraturan Menteri Kesehatan Republik Indonesia nomor 44 tahun 2016 tentang Pedoman Manajemen Puskesmas. Jakarta.

Yoku, Nick Alberto dkk. 2014. Proses Perencanaan Program Upaya Kesehatan Wajib (Basic Six) Pada Puskesmas di Kabupaten Keerom Propinsi Papua. e-journal Pascasarjana Universitas Hasanuddin Makasar.

https://pkmmlati2.slemankab.go.id/layana n/upaya-kesehatan-masyarakat/ Upaya Kesehatan Masyarakat Melati II. Sleman.Jogjakarta. 2016.

http://manajemenpelayanankesehatan.net/petunjukteknis-pelayanan-kesehatanprovinsi-riau/bab-iii-upayakesehatan/ PKMK FK UGM. 2017. 